\title{
Peningkatan Keterampilan Menulis Narasi Bahasa Inggris Melalui Teknik Pemetaan Pikiran (Penelitian Tindakan pada Mahasiswa UPT MKU Universitas Negeri Jakarta)
}

\author{
Ayatullah, \\ (Program studi Bahasa Inggris, Fakultas Ilmu Pendidikan Universitas MH. Thamrin)
}

\begin{abstract}
Abstrak
Tujuan penelitian ini adalah untuk meningkatkan kemampuan menulis melalui teknik peta pikiran. Teknik ini digunakan sebagai alternatif pembelajaran menulis untuk mengetahui teknik pembelajaran menulis yang terbaik dan tepat sehingga dapat digunakan dalam proses belajar mengajar. Data penelitian ini bersifat kualitatif. Data kualitatif diperoleh dengan mengamati proses belajar mengajar selama pelaksanaan tindakan, serta wawancara siswa dan kolaborator tentang tindakan yang diimplementasikan. Penelitian dilakukan di UPT MKU UNJ dengan subjek penelitian mahasiswa yang berjumlah 30 mahasiswa. Teknik penelitian yang digunakan adalah Penelitian Tindakan. Penelitian dilakukan sebanyak tiga siklus dan setiap siklusnya terdiri dari dua kali pertemuan. Setiap siklus terdiri dari perencanaan, tindakan, pengamatan, dan refleksi. Dari hasil analisis data kemampuan mahasiswa dan aktivitas mahasiswa menunjukkan bahwa hasil belajar mahasiswa siklus I memperoleh nilai ratarata aktivitas mahasiswa sebesar 46,5\% dan pada siklus II terdapat peningkatan menjadi 66,5\% kemudian meningkat lagi di siklus III menjadi 86,5\%. Berdasarkan hasil penelitian ini dapat disimpulkan bahwa penerapan teknik Peta Pikiran (mind mapping) pada pembelajaran Bahasa Inggris dapat meningkatkan kemampuan menulis karangan narasi di UPT MKU UNJ.
\end{abstract}

Kata Kunci: menulis narasi, teknik peta pikiran (mind mapping) 


\section{PENDAHULUAN}

Bahasa merupakan elemen dasar bagi setiap orang untuk saling berkomunikasi, berbagi pengalaman, belajar dari yang lain, serta untuk meningkatkan pengetahuan intelektual dan kesusastraan. Hal tersebut menjadikan bahasa memiliki peranan yang sangat penting dan memiliki fungsi yang sangat luas dan kompleks. Dalam dunia pendidikan, fungsi bahasa melalui proses pembelajaran di sekolah bertujuan mempersiapkan siswa untuk melakukan interaksi yang bermakna dengan bahasa yang alamiah. Kemampuan berbahasa berarti siswa diharapkan terampil menggunakan bahasa sebagai alat komunikasi dalam berinteraksi satu sama lain. Sehingga kemampuan ini diharapkan manfaatnya akan membantu perkembangan siswa dalam berhubungan dan beradaptasi dengan lingkungan sosialnya.

Begitu pula fungsi bahasa sebagai pengantar pendidikan di perguruan tinggi, keterampilan mahasiswa dalam berbahasa akan lebih bermakna dan bermanfaat dalam proses pembelajaran secara optimal. Interaksi yang bermakna bagi mahasiswa perlu direncanakan dalam program pembelajaran bahasa Inggris. Perencanaan yang bersifat kontekstual, konstruktif, komunikatif, integratif, dan kuantum dengan memperhatikan kompetensi dasar mahasiswa.

Bahasa Inggris merupakan salah satu mata pelajaran yang diajarkan di sekolah mulai dari tingkat menengah sampai perguruan tinggi. Bahasa Inggris merupakan bahasa kedua atau bahasa asing (foreign language) yang diajarkan di sekolah setelah bahasa pertama atau bahasa Indonesia. Oleh karenanya penguasaan bahasa baik lisan maupun tulisan merupakan keniscayaan, selain termasuk sebagai bahasa internasional yang sangat diperlukan khususnya dalam bidang pendidikan dan teknologi, terlebih dapat membuka cakrawala dunia sebagai jendela informasi dan membangun komunikasi masyarakat global..

Dalam Pedoman Khusus Pengembangan Silabus dan Penilaian, disebutkan bahwa tujuan pembelajaran bahasa haruslah lebih menekankan fungsi bahasa sebagai alat komunikasi daripada pembelajaran tentang sistem bahasa. Hal itu dilakukan dengan melibatkan seluruh kemampuan yang ada dalam belajar berupa: tubuh, gerak, pikiran, emosi, dan kecerdasan yang dimiliki mahasiswa. Tujuan lain adalah agar mahasiswa memperoleh pengajaran bahasa yang menyenangkan serta dapat merasakan manfaat praktisnya secara langsung dalam kehidupan sehari-hari.

Kurikulum Bahasa Inggris tingkat pendidikan tinggi pada mata kuliah bahasa Inggris di UPT MKU UNJ, pada hakikatnya hanya melanjutkan kurikulum di sekolah, khususnya kurikulum Sekolah Menengah Atas (SMA). Pada pembelajaran bahasa Inggris di SMA, siswa diajarkan keterampilan berbahasa yang meliputi dua aspek keterampilan berbahasa yaitu keterampilan reseptif dan keterampilan produktif. Keterampilan reseptif meliputi keterampilan menyimak (listening) dan keterampilan membaca (reading), sedangkan keterampilan produktif meliputi keterampilan berbicara (speaking) dan keterampilan menulis (writing).

Selain itu, dapat dikatakan bahwa tujuan pembelajaran bahasa Inggris bagi mahasiswa adalah untuk mengembangkan kemampuan atau keahlian berbahasa sesuai dengan kemampuan, kebutuhan, dan minatnya, sedangkan bagi dosen adalah untuk mengembangkan potensi bahasa Inggris mahasiswa, serta lebih mandiri dalam menentukan bahan ajar kebahasaan sesuai dengan kondisi lingkungan kampus dan kemampuan mahasiswa.

Di antara keempat aspek keterampilan berbahasa, menulis merupakan keterampilan berbahasa yang paling banyak diajarkan kepada mahasiswa agar mampu berkomunikasi, mengungkapkan gagasan, ide, dan penyaluran emosi dalam bentuk tertulis berupa karangan. Meskipun menulis merupakan keterampilan yang paling banyak diajarkan namun keterampilan menulis tidak dapat dipisahkan dari keterampilan berbahasa lainnya. Terutama, menulis sangat erat kaitannya dengan membaca. Semakin sering mahasiswa membaca maka akan semakin mudah untuk menulis.

Berdasarkan hasil praobservasi materi pembelajaran menulis di UPT MKU UNJ, terdapat beberapa keprihatinan. Penulis mengamati ketidakmampuan mahasiswa dalam menguasai menulis, salah satunya menulis karangan narasi. Sebagian dosen hanya menggunakan teknik menulis outline untuk merangsang mahasiswa mengembangkan gagasan utama, namun teknik tersebut ternyata belum mampu meningkatkan kemampuan menulis mahasiswa sehingga mahasiswa kesulitan dalam mengembangkan paragraf atau gagasan utama yang terdapat dalam pikirannya melalui tulisan. 
Berdasarkan hasil pretest penulisan karangan, terlihat mahasiswa masih banyak menggunakan tanda baca yang kurang tepat, penyusunan kalimat masih belum padu, kelogisan kalimat yang kurang jelas, dan pilihan kata yang kurang tepat sehingga kemampuan menulis mahasiswa masih belum memuaskan.

Salah satu kelemahan menulis mahasiswa ini disebabkan oleh kurangnya minat mahasiswa dalam membaca. Padahal, membaca sangat erat kaitannya dengan menulis. Kegiatan membaca jarang dilakukan oleh mahasiswa, sehingga menjadi salah satu hal yang menghambat kemampuan menulis. Selain itu, mahasiswa lebih banyak belajar mengenai teori aspek kebahasaan saja, namun jarang mempraktikkannya secara langsung dalam tulisan.

Pada umumnya, mahasiswa menyukai kegiatan menulis, akan tetapi dalam penerapannya mereka masih kesulitan untuk mengembangkan gagasan. Selain itu, mahasiswa terlihat kurang termotivasi apabila mendapatkan tugas menulis karangan. Terlebih, sarana yang mendukung kegiatan menulis kurang banyak terdapat di kelas, seperti: mading pada tiap kelas yang dapat diisi dengan karya mahasiswa.

Kesulitan-kesulitan yang dialami mahasiswa tersebut bisa diatasi dengan dosen dapat mengubah paradigmanya dalam berpikir untuk tidak melulu menerangkan teori menulis di dalam kelas. Dosen pada awal perkuliahan dapat menanamkan dalam diri mahasiswa mengenai manfaat menulis, karena pada dasarnya menulis sudah dilakukan anak sejak masih kecil, di samping anak belajar, mendengarkan, berbicara, dan membaca. Hal itu harus dilakukan karena menulis tidak dapat terjadi tanpa adanya motivasi. Kemampuan menulis dalam diri mahasiswa bersumber dari keingintahuannya terhadap informasi, sehingga pada akhirnya mahasiswa tersugesti untuk terus menulis apa yang ada dalam pikirannya secara bebas seperti halnya yang ia lakukan ketika dia berbicara.

Selain itu, dosen dapat memperkaya kembali proses pembelajaran berbahasa dengan menggunakan teknik pembelajaran yang tepat. Teknik ini dipraktikkan dosen di dalam kelas untuk mengefektifkan pengajaran dan diharapkan dapat memecahkan masalah dalam mengatasi kesulitan dan meningkatkan kemampuan menulis mahasiswa.

Salah satu teknik yang dirasakan penulis tepat dalam upaya meningkatkan prestasi menulis mahasiswa adalah melalui teknik peta pikiran (mind mapping). Dengan teknik ini diharapkan mahasiswa mampu mencatat kreatif dan memudahkan mahasiswa mengingat banyak informasi. Teknik ini ditemukan oleh Tony Buzan. yang sebelumnya muncul dari pengamatannya dalam bidang perkembangan teknologi komputer pada tahun 1971.

Teknik ini didasarkan pada teori kerja otak kita yang menyimpan banyak informasi dalam kotak-kotak sel syaraf yang tidak tersusun rapi, melainkan dikumpulkan dalam sel-sel syaraf yang bercabang-cabang seperti pohon. Dan apabila kita menyimpan informasi seperti cara kerja otak, maka tentu saja proses belajar dapat dilakukan dengan lebih mudah.

Cara kerja peta pikiran ini adalah dengan menuliskan tema utama sebagai titik sentral atau tengah dan memikirkan cabang-cabang atau tema-tema turunan yang keluar dari tengah tersebut dan mencari hubungan antara tema turunan. Sehingga diperkirakan akan memudahkan mahasiswa untuk mencari urutan kronologis suatu peristiwa, kejadian, dan masalah yang diharapkan. Mahasiswa juga akan lebih mudah jika dalam pembelajaran menulis narasi mengangkat tema dari kehidupan mahasiswa sehari-hari atau berdasarkan pengalaman pribadinya.

Berdasarkan penjelasan di atas, membuat penulis ingin meneliti lebih jauh mengenai efektivitas teknik peta pikiran dalam pembelajaran menulis di Perguruan Tinggi. Melalui teknik ini nantinya diharapkan dapat membantu mahasiswa untuk meningkatkan kemampuan menulis mahasiswa dalam pembelajaran karangan narasi. Selain itu, hal yang paling penting adalah penelitian ini dilakukan untuk memperbaiki kemampuan menulis di kampus, khususnya di kelas UPT MKU UNJ, Jakarta.

\section{KAJIAN TEORETIK}

Kemampuan (ability) adalah kecakapan atau potensi menguasai sesuatu keahlian yang merupakan bawaan sejak lahir atau merupakan hasil latihan atau praktek dan digunakan untuk mengerjakan sesuatu yang diwujudkan melalui tindakannya.

Sedangkan menulis merupakan salah satu dari empat keterampilan berbahasa. Setiap mahasiswa memiliki kemampuan berbahasa. Menulis, bahkan telah diajarkan ketika mahasiswa masih kelas 1 SD yang biasa 
dikenal dengan sebutan "calistung" (baca-tulis-hitung), kegiatan ini dilakukan sebagai pemahaman awal dalam memulai aktivitasnya pada saat mengembangkan kecerdasan berbahasa.

Akademi Kepengarangan dalam Widyamartaya menjelaskan bahwa menulis adalah kegiatan kompleks. Menulis dapat kita pahami sebagai "keseluruhan rangkaian kegiatan seseorang mengungkapkan gagasan dan menyampaikannya melalui bahasa tulis kepada pembaca untuk dipahami tepat seperti yang dimaksudkan oleh penulis." (A. Widyamartaya, 1990, h.9).

Dalam kehidupan modern saat ini, menulis telah menjadi kebiasaan yang dilakukan para pelajar. Kiranya tidak berlebihan apabila Tarigan mengatakan bahwa menulis dipergunakan oleh orang yang terpelajar dalam mencatat, meyakinkan, memberitahukan, dan mempengaruhi. Tujuan seperti itu dapat dicapai bila orang-orang mampu menyusun pikirannya dan mengutarakan gagasannya dengan jelas, berdasarkan pikiran, organisasi, pemakaiaan bahasa, serta tata tulis (kata-kata, dan ejaan).(Henry Guntur Tarigan, 1994, h. 3-4)

Leonhardt dalam Alwiyah menjelaskan bahwa tulisan yang bagus bukanlah keterampilan yang dapat dihasilkan sesuai dengan perintah. Artinya, membiarkan mahasiswa menulis sesuai keinginannya akan jauh lebih baik.

Agar hasil tulisan menjadi lebih baik, maka dalam kegiatannya akan dibutuhkan beberapa tahapan menulis seperti pendapat DePorter dalam Alwiyah bahwa ada tujuh tahapan dalam proses penulisan, antara lain: persiapan, draft-kasar, berbagi, perbaikan, penyuntingan, penulisan kembali, dan evaluasi. Adapun bahan-bahan yang dapat digunakan dalam pembelajaran menulis antara lain: buku catatan harian mahasiswa, sesuatu yang dialami bersamaan dan aktual, maupun dari gambar berseri. (Alwiyah Abdurrahman, 2001, h. 100)

Jenis tulisan yang menjadi acuan penulis dalam mengembangkan tulisannya, yaitu karangan narasi.

Karena karangan narasi merupakan jenis tulisan yang menceritakan kembali sebuah peristiwa.

Untuk menghasilkan tulisan narasi yang berkualitas dan bermutu, menulis narasi adalah menulis kronologi, artinya sangat memperhatikan dimana cerita itu terjadi dan kapan kejadian itu terjadi. Ada empat hal penting dalam penulisan narasi yaitu latar belakang, masalah, puncak masalah, dan penyelesaian. Latar belakang adalah hal-hal yang mendasari penulisan narasi yaitu karakter, tempat, dan waktu. Latar belakang ini akan memudahkan pembaca dalam mengikuti alur cerita. Kemudian terdapat masalah yang akan diselesaikan di akhir cerita. Masalah ini akan memuncak dan penuh dengan kejadiankejadian yang tidak terduga. Puncak masalah ini kemudian diikuti oleh penyelesaian masalah.

Sedangkan untuk penilaian menulis narasi dilakukan dalam bentu tes esai. Tes esai menuntut mahasiswa untuk dapat mengungkapkan fakta dengan bahasanya sendiri, mengorganisasikannya ke dalam koherensi yang logis kemudian menuangkan hasil pemikiran dalam ekspresi tertulis.

Ada beberapa tahapan dalam menilai tulisan narasi, antara lain: (1) menentukan bobot setiap aspek, (2) sebelum melakukan penilaian sebaiknya membaca terlebih dahulu beberapa karangan untuk dapat menentukan dasar penilaian, (3) penilai tidak mengetahui nama peserta yang dinilai, dan (4) untuk menentukan putusan akhir, diperlukan \pm 2 orang penilai.

Selanjutnya, Donn Byrne dalam Julian Dakin mengungkapkan langkah-langkah dalam penilaian yakni sebagai berikut:

1) Menunjukkan kesalahan sehingga mahasiswa dapat memperbaiki isinya. Hal ini biasanya dilakukan dengan memahami kesalahan yang terjadi.

2) Mengoreksi kesalahan.

3) Menjelaskan kesalahan.

4) Memberitahukan mahasiswa untuk berkonsultasi dengan tentang kesalahan.

5) Gunakan kesalahan sebagai dasar untuk pemberian pengajaran remedial. (Julian Dakin, 1979, p. 133)

Sedangkan untuk kriteria penilaiannya berpedoman dengan apa yang dikemukakan oleh Donn Byrne di atas bahwa untuk mengevaluasi karangan ditetapkan aspek penilaian organisasi karangan narasi yaitu: (a) berplot dan kronologis, (b) isi (kejelasan dan keluasan isi), (c) kebahasaan, struktur kalimat dan (d) tata tulis (kata-kata, dan ejaan). 
Berdasarkan penjelasan di atas, menilai tulisan narasi mahasiswa kelas IV SD membutuhkan pertimbangan khusus dengan memperhatikan karakteristik yang dimiliki mahasiswa SD. Untuk itu, peneliti memodifikasi penilaian dengan menitikberatkan pada indikator sesuai dengan karakteristik tulisan narasi.

Sedangkan, untuk menentukan tingkat kemampuan menulis mahasiswa dipergunakan alat penilaian atau rubrik juga sebagai standardisasi penilaian tes dalam pembelajaran menulis bahasa Inggris Kemampuan seseorang dalam menulis narasi berarti mengetahui, memahami, dan dapat menggunakan kaidah-kaidah bahasa Inggris seperti organisasi awal, struktur bahasa dalam tataran kebahasaan dan kosakata serta ejaan yang baik dan benar dalam tata tulisnya..

Jadi, dapat disimpulkan bahwa kemampuan menulis narasi adalah kemampuan menyusun ide pikiran dan mengutarakannya dengan jelas yang ditulis sesuai konflik serta menekankan susunan kronologis berdasarkan organisasi pikiran, pemakaiaan bahasa, serta tata tulis (kata-kata, dan ejaan) agar dapat dipahami secara baik oleh pembaca.

Sedangkan acuan teori rancangan-rancangan alternatif tindakan yang dipilih berupa Teknik Peta Pikiran (Mind Mapping).

Salah satu teknik pembelajaran yang telah terbukti mampu mengoptimalkan hasil belajar adalah teknik peta pikiran atau disebut mind mapping. Peta pikiran merupakan teknik yang pertama kali diperkenalkan oleh Buzan pada awal 1970-an. Buzan mengungkapkan bahwa mind mapping adalah cara mencatat yang kreatif, efektif, dan secara hafiah yang akan "memetakan" pikiran.(Susi Purwoko, 2006, h. 4). Hal ini dimaksudkan dengan menggunakan peta pikiran, akan memudahkan memasukkan informasi ke otak, dan untuk mengambil informasi dari otak. Peta pikiran selalu menggunakan warna dan struktur alaminya berupa radial yang memancar keluar dari gambar sentral. Mind mapping menggunakan garis, lambang, kata-kata, serta gambar yang akrab bagi otak. Maka dari itu, daftar informasi yang panjang bisa diubah bentuknya menjadi diagram berwarna-warni, mudah diingat dan sangat beraturan serta sejalan dengan cara kerja alami otak.

Teknik peta pikiran (mind mapping) terlahir untuk mengatasi kebuntuan dalam menuangkan gagasan yang ada dalam pikiran, terutama dalam bentuk tertulis. Selanjutnya, Wycoff mengemukakan bahwa peta pikiran adalah cara yang sangat baik untuk menghasilkan dan menata gagasan sebelum mulai menulis. (Wycoff, 1990, h. 83). Melalui teknik peta pikiran dapat mengatasi kebuntuan dan rintangan dalam menulis. Sehingga mampu mengeksplorasi ide-ide yang ingin ditulis secara bebas, mengungkapkan ketidaktahuan pada saat menulis secara rinci, sampai akhirnya penulis tersadar bahwa sebenarnya banyak sekali ide yang bermunculan di otak kita.

Teknik peta pikiran bukan hanya memberikan penekanan kepada aspek kebahasaan. Terkait dengan teknik ini, belahan otak kiri yang lebih sering dipaksa untuk berpikir, diseimbangkan dengan penekanan pada belahan otak kanan, melalui pengembangan imajinasi, gambar, dan warna dalam berbagai rangkaian pola yang menarik. Teknik ini merupakan contoh sederhana untuk membuat anak menjadi lebih kreatif dalam mengelompokkan gagasan melalui hal yang sederhana.

Langkah-langkah Membuat Peta Pikiran (Mind mapping) ada tujuh. Tujuh langkah tersebut dimulai dari bagian tengah kertas kosong yang diletakkan mendatar (landscape). Kemudian menggunakan gambar atau foto untuk sentral serta warna yang menarik. Selanjutnya menghubungkan cabang-cabang utama ke gambar pusat dan hubungkan cabang-cabang tingkat dua dan tingkat tiga ke tingkat satu dan dua, dan seterusnya. Lalu membuat garis hubung yang melengkung, bukan garis lurus karena dengan garis lurus akan membosankan otak. Dan menggunakan satu kata kunci untuk setiap garis karena dengan kata kunci tunggal dapat memberi lebih banyak daya dan fleksibilitas kepada peta pikiran (mind mapping). Selain itu juga menggunakan gambar karena seperti gambar sentral, setiap gambar bermakna seribu kata. (Buzan, 1993, h. 15)

Maka, Kemampuan menulis narasi merupakan kecakapan mahasiswa dalam mengungkapkan ide pikiran dan pengalaman dalam suatu rangkaian waktu yang dituangkan dengan menggunakan lambang atau simbol berupa angka atau huruf yang disampaikan kepada pembaca. Dalam menulis narasi yang perlu menjadi perhatian utama adalah urutan waktu dari sebuah wacana tersebut dan aspek berikut ini oleh 
penulis dijadikan indikator penilaian dalam kemampuan menulis narasi yaitu kesesuaian isi atau gagasan, pengorganisasian, kebahasaan, serta tata tulis (huruf kapital, tanda titik, dan tanda koma).

Penggunaan teknik yang berdasarkan perkembangan kognitif mahasiswa secara tepat yakni teknik Peta Pikiran (Mind Mapping). Cara kerja peta pikiran ini adalah dengan menuliskan tema utama sebagai titik sentral atau tengah dan memikirkan cabang-cabang atau tema-tema turunan yang keluar dari tengah tersebut dan mencari hubungan antara tema turunan. Sehingga akan memudahkan mahasiswa untuk mencari urutan kronologis suatu peristiwa, kejadian, dan masalah yang diharapkan serta dapat meningkatkan pemahaman mahasiswa dan mahasiswa dapat berfikir kritis.

Berdasarkan uraian tersebut, maka teknik peta pikiran (mind mapping) dapat meningkatkan kemampuan menulis karangan narasi pada mahasiswa UPT MKU UNJ, Jakarta.

\section{METODOLOGI PENELITIAN}

Subjek dalam penelitian ini adalah mahasiswa UPT MKU UNJ yang berjumlah 1 kelas. Subjek penelitian berjumlah 33 orang (1 kelas) diambil dengan cara diacak secara sederhana.

Dalam penelitian tindakan peran peneliti harus terlibat langsung secara terus menerus di dalam proses penelitian sejak awal sampai dengan hasil penelitian. Selanjutnya peneliti memantau, mencatat dan mengumpulkan data, lalu menganalisis data serta berakhir dengan melaporkan hasil penelitiannya.

Instrumen peningkatan keterampilan menulis yang digunakan dalam penelitian ini berbentuk tes tulis dan observasi. Untuk menentukan tingkat keterampilan menulis siswa dipergunakan alat penilaian atau rubrik juga sebagai standardisasi penilaian tes dalam pemelajaran menulis bahasa Inggris. Tes ini dirancang sendiri oleh peneliti sehingga sebelum digunakan peneliti mengujicobakannya terlebih dahulu. Uji coba dilakukan untuk memperoleh butir-butir instrumen yang baik, dapat mengukur secara tepat (valid) dan tetap (reliable). Tes tersebut diujicobakan pada 20 orang siswa yang tidak termasuk dalam sampel penelitian.

Penelitian ini menggunakan pendekatan kualitatif maka peneliti sendiri sebagai instrumen utama penelitian atau alat pengumpul data. Instrumen yang digunakan untuk mengumpulkan data adalah tes, wawancara, observasi foto, dan portofolio penelitian.

Pengumpulan data dilakukan pada setiap siklus dimulai dari awal sampai berakhirnya tindakan siklus 1 sampai siklus 2. Peneliti mengamati aktivitas mahasiswa dalam kegiatan menulis bahasa Inggris dan pemahaman mereka pada materi yang disampaikan. Pengamatan ini dilakukan pada setiap siklus ketika pembelajaran menulis dengan peta pikiran dilaksanakan.

Untuk memperjelas keterangan di atas, dikemukakan hasil tes formatif mahasiswa pada akhir siklus pertama menunjukkan; bahwa mahasiswa yang mendapatkan skor 85-100 (kriteria A) sebanyak 4 mahasiswa atau 15,38\%, skor 70-84 (kriteria B) sebanyak 7 mahasiswa atau 26,92\%, skor 55-69 (kriteria

C) sebanyak 15 mahasiswa atau 57,69\%, skor 40-54 (kriteria D) tidak ada atau 0\% dan skor $\leq 40$ (kriteria

E) tidak ada atau $0 \%$.

Berdasarkan hasil analisis kemampuan menulis narasi dengan teknik Peta Pikiran pada siklus I ini belum berhasil mencapai nilai yang ditargetkan. Namun apabila membandingkan hasil yang didapat pada siklus I dengan hasil yang didapat pada praintervensi tindakan terjadi sedikit peningkatan nilai kemampuan menulis mahasiswa.

\section{HASIL DAN PEMBAHASAN}

Berdasarkan hasil analisis kemampuan menulis narasi dengan teknik Peta Pikiran pada siklus pertama hingga ketiga ini sudah mencapai nilai yang ditargetkan. Hal ini terbukti dari empat aspek penilaian pada siklus I-III, peneliti mengungkapkan bahwa rerata hasil kemampuan menulis mahasiswa pada siklus I 69,30\% (cukup), siklus II 76,73\% (baik), dan pada siklus III 80,85\% (baik). Jadi, dapat disimpulkan bahwa pembelajaran menulis narasi dengan menggunakan teknik peta pikiran cenderung menunjukkan hasil yang meningkat dari siklus I, siklus II, dan siklus III. 
Tabel

Tabel Hasil Penelitian Menggunakan Teknik Peta Pikiran (Mind Mapping)

\begin{tabular}{|l|l|l|}
\hline Penelitian & $\begin{array}{l}\text { Presentase Hasil } \\
\text { Menulis } \\
\text { Mahasiswa }\end{array}$ & $\begin{array}{l}\text { Pemantau } \\
\text { Tindakan } \\
\text { Dosen dan } \\
\text { Mahasiswa }\end{array}$ \\
\hline Siklus I & $69,30 \%$ & $46,5 \%$ \\
\hline Siklus II & $76,73 \%$ & $66,5 \%$ \\
\hline Siklus III & $80,85 \%$ & $86,5 \%$ \\
\hline
\end{tabular}

Hasil ini kemudian mengatakan bahwa penelitian tindakan kemampuan menulis karangan melalui teknik peta pikiran dapat dikatakan berhasil.

Secara kualitatif, keberhasilan ini juga terlihat dalam data pemantau tindakan, dan catatan lapangan. Peningkatan tersebut dipengaruhi oleh kegiatan beragam yang dipilih peneliti untuk mengembangkan kemampuan menulis dengan melibatkan kemampuan berbahasa yang lain seperti mengamati, mendengar dan berbicara, serta beberapa faktor pendukung lainnya seperti secara teknis, peneliti melakukan persiapan yang matang baik dalam segi peralatan atau pengaturan ruangan, menggunakan media, memperbanyak penguatan positif dan mengurangi intervensi, memberi kesempatan pada anak untuk berekspresi, membuat peraturan bersama dengan anak untuk membentuk perilaku tertentu, memberi contoh dengan percaya diri pada anak, memberikan penjelasan langkah-langkah kegiatan dengan detail, dan mengatur alokasi waktu dengan banyak kegiatan secara proporsional. Hasil yang akan dicapai akan lebih maksimal jika dosen secara konsisten menerapkan perubahan tersebut dalam proses pembelajaran.

Jadi, dapat disimpulkan sesuai dengan penelitian siklus pertama hingga siklus ketiga bahwa (1) penggunaan teknik peta pikiran dapat memotivasi mahasiswa untuk belajar dengan gembira, bebas, aktif, dan produktif, sehingga kendala psikologis yang menghambat mahasiswa dapat teratasi. (2) Intensitas kemampuan menulis mahasiswa semakin meningkat, yaitu dari kurang lancar menulis menjadi lancar dan mudah menuangkan perasaan, pikiran, dan interpretasinya. (3) Hasil pembelajaran menulis narasi mahasiswa semakin meningkat, dari semula kurang mampu mengembangkan ide-ide pokok yang ada dalam gambar peta pikiran menjadi lebih baik. (4) Mahasiswa terlatih dalam berbagai hal atau pengalaman, seperti berani mengungkapkan pendapat dan mau menerima perbedaan pendapat. (5) Peneliti selaku dosen sementara berubah fungsi dari seorang penyampai pengetahuan berubah menjadi fasilitator, dinamisator, dan motivator.

Berdasarkan penjabaran tersebut maka dapat dikatakan bahwa teknik peta pikiran dapat meningkatkan kemampuan menulis mahasiswa dapat diterima.

\section{PENUTUP}

Berdasarkan temuan yang ada dalam penelitian tindakan kelas dalam tiga siklus selama enam kali pertemuan, dengan menggunakan teknik peta pikiran (mind mapping) mampu menyimpan kesan dalam memori dengan baik dan teratur karena dilakukan secara aktif oleh mahasiswa. Kegiatan yang menarik, menyenangkan, dan menantang bagi mahasiswa seperti brainstorming, tanya jawab, diskusi terkait teknik peta pikiran dalam pembelajaran menulis akan memberi kesan tersendiri pada mahasiswa.

Teknik peta pikiran (mind mapping) merupakan teknik belajar sebagai cara mudah memasukkan informasi ke otak, dan untuk mengambil informasi dari otak dalam mengeksplorasi ide-ide yang ingin ditulis secara bebas, dan mengungkapkan ketidaktahuan pada saat menulis secara rinci sehingga mahasiswa mendapat kemudahan dalam menuangkan ide serta gagasannya dalam bentuk tertulis.

Dalam menerapkan teknik peta pikiran ini di kampus dibutuhkan komitmen yang tinggi dari dosen, karena dalam pelaksanaannya dibutuhkan perencanaan yang baik dan membutuhkan kreativitas dosen dalam membantu mahasiswa untuk memahami proses menulis karangan narasi. Diharapkan dengan penggunaan teknik ini proses pembelajaran menjadi lebih bermakna dan dapat dipertimbangkan untuk mengembangkan teknik pembelajaran bagi dosen dalam memberikan materi pelajaran kepada mahasiswa. 
Berdasarkan penjelasan di atas, dapat disimpulkan bahwa pembelajaran menulis narasi melalui teknik peta pikiran terbukti cukup efektif dan dapat meningkatkan kemampuan menulis mahasiswa dalam pembelajaran Bahasa Inggris.

Berdasarkan kesimpulan dan implikasi di atas, maka dapat dikemukakan saran sebagai berikut:

Pertama, Dosen diharapkan dapat memberi dukungan moril maupun materil dalam inovasi pembelajaran menulis narasi. Dukungan moril dapat dituangkan dalam sebuah buku pedoman yang berisikan teknik atau teknik pembelajaran yang inovatif. Sedangkan dukungan materil dapat berupa fasilitas sumber atau media belajar yang mendukung proses pembelajaran dan disosialisasikan mengenai cara penggunaannya.

Kedua, Memberikan penghargaan terhadap dosen yang sudah mampu berinovasi dalam setiap pembelajaran atau telah mencapai kompetensi yang diharapkan. Sehingga dosen tersebut akan terus meningkatkan kualitas dalam mengajar serta mendidik mahasiswa.

Ketiga, Pada Lembaga Pendidikan Tenaga Kependidikan yang menghasilkan tenaga pendidik, hendaknya selalu mengikuti perkembangan mengenai teknik pembelajaran yang tepat untuk mengajarkan Bahasa Inggris.

Keempat, Peneliti lain dalam melaksanakan penelitian lanjutan terkait dengan permasalahan dalam penelitian ini, diharapkan lebih mengoptimalkan faktor-faktor pendukung pelaksana penelitian

\section{DAFTAR PUSTAKA}

Akhadiah, S., Arsjad, M.G. \& Ridwan, S.H. Pembinaan Kemampuan Menulis Bahasa Inggris. Jakarta:

Erlangga, 1991

Arikunto. Prosedur Penelitian. Jakarta: Rineka Cipta, 2006

BSNP. Standar Isi (Keputusan Menteri No. 22, 23, 24 Tahun 2007) Badan $\quad$ Standar $\quad$ Nasional

Pendidikan. Jakarta: BSNP, 2007

Buzan, Tony, Use both side your brain, diterjemahkan oleh F Anmy Boediman

(Surabaya: Ikon, 2003).

Depdiknas, Pengembangan Silabus dan Penilaian Mata Pelajaran Bahasa dan Sastra

Inggris (Depdiknas: Jakarta, 2003),

DePorter, Bobbi; Reardon, Mark; Singer-Nourie, Sarah. Quantum Teaching: $\quad$ Mempraktikkan

Quantum Learning di Ruang-ruang Kelas. Terjemahan Ary Nilandari. Bandung: Kaifa, 2001

Nurgiyantoro, Burhan, Penilaian dalam Pengajaran Bahasa dan Sastra (Yogyakarta:

BPFE, 1995),

Sugiyono, Memahami Penelitian Kualitatif. (Bandung: Alfabeta, 2008). 
